\title{
PENGEMBANGAN KAPASITAS APARATUR SIPIL NEGARA DI BADAN KEPEGAWAIAN PENDIDIKAN PELATIHAN KABUPATEN GORONTALO UTARA
}

\author{
Nurhayati Van Gobel \& Sofyan Alhadar \\ STIA Bina Taruna Gorontalo \\ bukujurnalstia@binataruna.ac.id ${ }^{1}$ \& sofyanalhaddar654@gmail.com²
}

\begin{abstract}
ABSTRAK
Tujuan penelitian ini adalah untuk mengetahui bagaimana pengembangan kapasitas aparatur sipil negara di Badan Kepegawaian Pendidikan Pelatihan Kabupaten Gorontalo Utara. Metode penelitian ini adalah deskriptif dengan pendekatan kualitatif. Pengumpulan data diperoleh dari data primer yaitu wawancara, dan data sekunder dari buku dan jurnal. Fokus penelitian adalah pendidikan dan pelatihan, peran pimpinan, dan kompetensi.

Hasil penelitian menunjukkan bahwa sebagian besar aparatur belum mengikuti pendidikan dan pelatihan; peran pimpinan belum maksimal dalam mendorong dan memotivasi para aparaturnya, oleh karena belum mengikuti pendidikan dan pelatihan sesuai dengan bidang ilmu serta penugasan sehingga kompetensi aparatur masih rendah.

Untuk itu disarankan agar aparatur meningkatkan kapasitas dengan mengikuti pendidikan dan pelatihan sesuai dengan bidang ilmunya; agar pimpinan senantiasa mendorong dan memotivasi aparatur untuk terus mengembangkan kapasitas bawahnnya, agar kompetensi menjadi lebih baik maka sudah selayaknya aparatur tidak berhenti mengembangkan kapasitasnya.
\end{abstract}

\section{Kata Kunci: Pengembangan; Kapasitas; ASN}

\section{PENDAHULUAN}

Untuk mewujudkan sistem pemerintahan yang bersih dan berwibawa (Good Governance) serta mewujudkan pelayanan publik yang baik, efisien, efektif dan berkualitas tentunya perlu didukung adanya Sumber Daya Manusia (SDM) aparatur khususnya Aparatur Sipil Negara yang profesional, bertanggungjawab, adil, jujur dan kompeten dalam bidangnya. Dengan kata lain, Aparatur Sipil Negara dalam menjalankan tugas tentunya harus berdasarkan pada profesionalisme dan kompetensi sesuai kualifikasi bidang ilmu yang dimilikinya.

Dalam rangka penyelenggaraan tugas-tugas pemerintahan dan pelayanan umum maka perlu didukung dengan sumberdaya aparatur yang kompeten. Persoalan kompetensi aparatur memang merupakan determinan penting mengingat di pundak aparatur memiliki tugas ganda, selain dituntut harus mampu memberikan layanan pada masyarakat secara adil dan transparan, dan juga harus mampu menunjukkan loyalitas, dedikasi dan etos kerja serta integritas yang tinggi. 
Tugas ganda tersebut akan dapat terealisasi didukung dengan kompetensi aparatur yang professional.

Pemerintah

Kabupaten

Gorontalo Utara diharapkan dapat menerapkan pembinaan kepegawaian pada perangkat daerah di Kantor Badan Kepegawaian Pendidikan Pelatihan Kabupaten Gorontalo Utara dan sekaligus untuk memastikan para pemangku jabatan pimpinan perangkat daerah, jabatan administrator dan jabatan pengawas di lingkungan pemerintahan daerah mempunyai pengetahuan, sikap dan ketrampilan yang memadai dalam memangku tugas-tugas pemerintahan.

Namun kenyataannya di Kantor Badan Kepegawaian Pendidikan dan Pelatihan Kabupaten Gorontalo Utara sebagian besar pegawai belum mengikuti diklat kepemimpinan, diklat teknis dan diklat fungsional, hal ini terlihat dari kemampuan pegawai di Kantor Badan Kepegawaian Pendidikan Pelatihan Kabupaten Gorontalo Utara masih lambat dan kurang efektif dalam menyelesaikan pekerjaannya. Selain itu masih banyak pegawai yang bekerja di luar keahlian dan tidak sesuai dengan bidang Pendidikannya. Karena itu mengiringi persoalan yang terus berkembang, maka perlu tindakan yang aplikatif yaitu mengembangkan kompetensi aparatur, melalui pendidikan dan pelatihan. Peran Pimpinan juga sangat menunjang pengembangan kapasitas ASN namun sampai dengan saat ini Kepala Kantor Badan Kepegawaian Pendidikan Pelatihan Kabupaten Gorontalo Utara tidak melaksanakan rotasi pekerjaan terhadap pegawai yang menduduki jabatan struktural namun belum mengikuti diklat kepemimpinan. Perlunya pengembangan kompetensi aparatur mengingat terbatasnya aparatur yang memiliki legalitas pelatihan sesuai bidang kerjanya, adanya ketidakserasian antara bidang pekerjaan dengan keterampilan dan keahlian, beragamnya kompetensi aparatur yang memungkinkan hasil kerja secara totalitas kurang optimal. Ketidakseimbangan antara beban kerja dengan kompetensi aparatur, hal ini terlihat dari pekerjaan yang hanya dibebankan kepada satu orang pegawai saja padahal masih banyak pegawai yang berkompotensi namun belum bisa bekerja secara optimal.

\section{PERMASALAHAN}

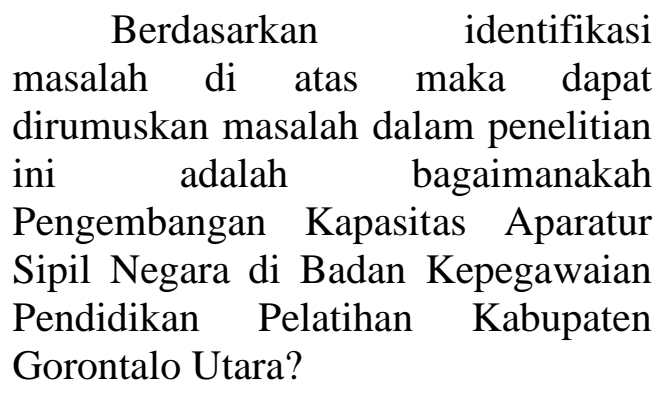

\section{TUJUAN DAN MANFAAT PENELITIAN}

\section{Tujuan Penelitian}

Tujuan dalam penelitian ini
dalah untuk mengetahui Pengembangan Kapasitas Aparatur Sipil Negara di Badan Kepegawaian Pendidikan Pelatihan Kabupaten Gorontalo Utara

\section{Manfaat Penelitian}

Manfaat dalam penelitian permasalahan ini adalah: Manfaat Teoritis 
Manfaat penelitian ini diharapkan dapat memberikan sumbangan dalam mengembangkan ilmu pengetahuan pada umumnya dan bidang Administrasi Publik pada khususnya. Manfaat Praktis

Penelitian ini bermanfaat bagi lembaga Badan Kepegawaian Pendidikan Pelatihan Kabupaten Gorontalo Utara sebagai masukan dalam meningkatkan dan mengembangkan kinerja Aparatur Sipil Negara

\section{METODE PENELITIAN}

Penelitian ini dilaksanakan di Kantor Badan Kepegawaian Pendidikan Pelatihan Kabupaten Gorontalo Utara dengan alasan, ingin mengetahui sejauh mana Pengembangan Kapasitas Aparatur Sipil Negara di Badan Kepegawaian Pendidikan Pelatihan Kabupaten Gorontalo Utara, dan dengan lokasinya memudahkan peneliti untuk mengumpulkan data karena mudah terjangkau sehingga ditinjau dari segi waktu, tenaga dan biaya tidak memberatkan peneliti serta memiliki hubungan kerja dengan lingkup permasalahan yang akan diteliti sehingga memahami dengan benar permasalahan yang akan diteliti.

Penelitian ini adalah jenis penelitian deskriptif dengan menggunakan pendekatan kualitatif, Pengertian Deskriptif Kualitatif yaitu suatu prosedur penelitian yang menggunakan data deskriptif berupa kata-kata tertulis atau lisan dari orang-orang dan pelaku yang dapat diamati. Metode penelitian kualitatif, sebagai sebuah metode penelitian, memiliki lima belas indikator / ciri sebagai berikut.

a. Sumber data adalah situasi yang wajar atau natural setting.

b. Peneliti sebagai instrumen penelitian. Peneliti adalah key instrument, alat penelitian utama.

c. Sangat diskriptif

d. Mementingkan proses maupun produk, jadi juga memperhatikan bagaimana perkembangan terjadinya sesuatu.

e. Mencari makna di belakang kelakuan atau perbuatan sehingga dapat memahami masalah atau situasi.

Berdasarkan pengertian tersebut dapat disimpulkan bahwa penelitian deskriptif kualitatif bertujuan untuk mengangkat fakta, keadaan, variabel, dan fenomena-fenomena yang terjadi ketika penelitian berlangsung dan menyajikannya apa adanya.

\section{Fokus Penelitian}

Penelitian ini difokuskan pada Pengembangan Kapasitas Aparatur Sipil Negara di Badan Kepegawaian Pendidikan Pelatihan Kabupaten Gorontalo Utara yang melihat pada pendidikan dan pelatihan, peran pemimpin dan kompetensi aparat sebagai berikut:

\section{Pendidikan dan Pelatihan}

Pendidikan dan Pelatihan yang dimaksud dalam penelitian adalah pendidikan dan pelatihan yang seharusnya diikuti oleh aparatur dalam rangka mengembangkan kapasitas mereka.

\section{Peran Pemimpin}

Peran pemimpin yang dimaksud dalam penelitian ini adalah bagaimana seorang pemimpin memberikan motivasi kepada para 
aparaturnya untuk terus meningkatkan kapasitas mereka.

\section{Kompetensi}

Kompetensi yang dimaksud dalam penelitian ini adalah kemampuan para aparatur dalam melaksanakan tugas dan kewajiban mereka dalam pekerjaan mereka.

\section{HASIL PENELITIAN DAN PEMBAHASAN}

Pelatihan dan pengembangan merupakan usaha mengurangi atau menghilangkan terjadinya kesenjangan antara kemampuan karyawan dengan yang dikehendaki organisasi. Adanya kesenjangan antara kemampuan karyawan dengan yang dikehendaki organisasi, menyebabkan perlunya organisasi menjembatani kesenjangan tersebut, salah satu caranya pelatihan dan pengembangan. Dengan demikian diharapkan seluruh potensi yang dimiliki karyawan, yaitu keterampilan, pengetahuan, dan sikap dapat ditingkatkan, akhirnya kesenjangan berkurang atau tidak terjadi lagi kesenjangan.

Pengembangan kapasitas

Aparatur Sipil Negara di Kantor Badan Kepegawaian Pendidikan Pelatihan Kabupaten Gorontalo Utara dalam penelitian ini terdapat tiga aspek yakni: pendidikan dan pelatihan, peran pemimpin dan kompetensi.

Pengembangan kapasitas

Aparatur Sipil Negara melalui Pendidikan dan Pelatihan untuk mengembangkan sumber daya manusia melalui rangkaian, kegiatan identifikasi, pengkajian serta proses belajar yang terencana. Namun berdasarkan hasil wawancara diperoleh bahwa pendidikan dan pelatihan di Kantor Badan Kepegawaian Pendidikan Pelatihan Kabupaten Gorontalo Utara belum berjalan dengan baik. Hal ini terlihat dari faktor biaya pendidikan dan pelatihan yang harus ditanggung oleh pegawai bersangkutan dan kurangnya komunikasi antara pegawai mengenai pendidikan dan pelatihan yang akan diikuti.

Sementara itu dalam Pengembangan kapasitas Aparatur Sipil Negara di Kantor Badan Kepegawaian Pendidikan Pelatihan Kabupaten Gorontalo Utara peran pemimpin sangat menunjang. berdasarkan yang terjadi di lapangan pengembangan kapasitas Aparatur Sipil Negara di Kantor Badan Kepegawaian Pendidikan Dan Pelatihan Kabupaten Gorontalo Utara dilihat dari segi peran pemimpin sudah optimal. Kepala Badan Kepegawaian Pendidikan Dan Pelatihan Kabupaten Gorontalo Utara selalu memberikan masukan, motivasi dan kesempatan untuk berprestasi kepada pegawainya.

Di samping itu dengan adanya kompetensi organisasi dapat menentukan standar pengetahuan, keahlian, kemampuan kerja seseorang atas bidang tertentu. Namun menurut hasil wawancara diperoleh bahwa kompetensi di Kantor Badan Kepegawaian Pendidikan Pelatihan Kabupaten Gorontalo Utara masih kurang optimal. Di pengaruhi oleh kurangnya kinerja pegawai dan tidak ada tanggung jawab dari sebagian pegawai terhadap pekerjaan yang dibebankan padanya. 


\section{SIMPULAN}

Dari hasil penelitian dapat diperoleh kesimpulan sebagai berikut

1. Pendidikan dan Pelatihan dalam Pengembangan kapasitas Aparatur Sipil Negara di Kantor Badan Kepegawaian Pendidikan Pelatihan Kabupaten Gorontalo Utara belum berjalan dengan baik. Hal ini terlihat dari faktor biaya pendidikan dan pelatihan yang harus ditanggung oleh pegawai bersangkutan dan kurangnya komunikasi antara pegawai mengenai pendidikan dan pelatihan yang akan diikuti.

2. Peran Pemimpin dalam Pengembangan kapasitas Aparatur Sipil Negara di Kantor Badan Kepegawaian Pendidikan Pelatihan Kabupaten Gorontalo Utara sudah optimal. Kepala Badan Kepegawaian Pendidikan Dan Pelatihan Kabupaten Gorontalo Utara selalu memberikan masukan, motivasi dan kesempatan untuk berprestasi kepada pegawainya.

3. Kompetensi dalam Pengembangan kapasitas Aparatur Sipil Negara di Kantor Badan Kepegawaian Pendidikan Pelatihan Kabupaten Gorontalo Utara kurang optimal. Di pengaruhi oleh kurangnya kinerja pegawai dan tidak ada tanggung jawab dari sebagian pegawai terhadap pekerjaan yang dibebankan padanya.

\section{SARAN}

Adapun saran dalam penelitian ini adalah:

1. Diharapkan kepada Aparatur Sipil Negara di Kantor Badan
Kepegawaian Pendidikan Pelatihan Kabupaten Gorontalo Utara untuk mengikuti pendidikan dan pelatihan yang diselenggarakan oleh kantor agar tercipta Aparatur Sipil Negara yang profesional dan berdaya saing.

2. Diharapkan kepada Aparatur Sipil Negara di Kantor Badan Kepegawaian Pendidikan Pelatihan Kabupaten Gorontalo Utara untuk lebih menggunakan peluang yang diberikan pimpinan dalam berprestasi

3. Diharapkan kepada Aparatur Sipil Negara di Kantor Badan Kepegawaian Pendidikan Pelatihan Kabupaten Gorontalo Utara agar lebih berkompeten untuk meningkatkan kinerjanya.

\section{DAFTAR PUSTAKA}

Andi, Prastowo. 2012. Metode Penelitian Kualitatif. Yogyakarta: Ar - Ruzz Media.

Anwar, Prabu, Mangkunegara. 2013. MSDM Perusahaan. Bandung: Remaja Rosdakarya.

Dahar. 2011. Teori Belajar dan Pembelajaran. Jakarta: Erlangga.

Daryanto. 2011. Administrasi Pendidikan. Jakarta: Rineka Cipta.

Dessler, Gary. 2011. Manajamen Sumber Daya Manusia. Jakarta: Indeks. 2015. Manajamen Sumber Daya Manusia. Jakarta: Salemba Empat.

Dwiyanto, Agus. 2010. Manajemen Kinerja Sektor Publik. Yogyakarta: UPP STIM, YKPN 
Edy, Sutrisno. 2015. Manajemen SDM. Jakarta: Kencana.

Effendi, Sofian. 2010. Reformasi Data Kepemerintahan. Yogyakarta: Gajahmada.

Handoko, T, Hani. 2011. Manajemen Personalia SDM. Yogyakarta: BFEE.

Hasibuan, Malayu. 2011. Manajemen Sumber Daya Manusia. Jakarta: Bumi Aksara.

Herman, Sofyandi. 2009. Manajemen Sumber Daya Manusia, terjemahan. Jakarta: PT. Prenhalindo.

Kaswan. 2012. Manajemen Sumber Daya Manusia Untuk Keungulan Bersaing Organisasi. Jakarta: Graha Ilmu.

Keban, Yeremias T. 2008. Enam Dimensi strategis Administrasi Publik, Konsep, Teori dan Isu, Yogyakarta: Gaya Media.

Ma'arif, Syamsul dan Kartika Lindawaty. 2012. Kinerja Sumber Daya Manusia. Bogor: IPB Press.

Mangkunegara. 2008. Manajemen Sumber Daya Manusia Perusahaan. Bandung: Remaja Rosdakarya.

Mangkuprawira. 2011. Manajemen Sumber Daya Manusia Strategik. Jakarta: Ghalia Indonesia.

Marwansyah. 2010. Manajemen Sumber Daya Manusia. Edisi Kedua. Bandung: Alfabeta.

Moh. Pabundu Tika. 2010. Budaya Organisasi dan Peningkatan Kinerja Perusahaan. Jakarta: PT Bumi Aksara.
Mondy R. Wayne. 2010. Human Resource Management Elevent, New Jesrey.

Ratminto dan Winarsih. 2010. Manajemen Pelayanan, Yogyakarta: Pustaka Jaya.

Rivai, dan Sagala, 2013, Manajemen SDM Untuk Perusahaan Dan Teori Ke Praktek. Edisi Kedua Cetakan Kelima. Jakarta: PT. Praja Grafindo Persada.

Robbins, dan Coulter. 2014. Manajemen. Diterjemahkan oleh Bob Sabran, Wibi Handani. Jakarta: Erlangga.

Sagala, Syaiful. 2010. Administrasi Pendidikan. Bandung: Alfabeta.

Sangkala. 2012. Dimensi-dimensi Manajemen Publik. Yogyakarta: Ombak.

Saroni, Mohamad. 2011. Personal Branding Guru. Yogjakarta: Ar-Ruzz Media.

Sedarmayanti. 2010. Manajemen Sumber Daya Manusia. (Reformasi Birokrasi Dan Manajemen PNS). Bandung: Refika Aditama.

Simamora, Henry. 2009. Manajemen Sumber Daya Manusia. Jakarta: Rhineka Cipta.

Sinambela. 2008. Reformasi Pelayanan Publik, Teori, Kebijakan Dan Implementasi, Jakarta: Bumi Aksara.

Sulistiyani dan Rosidah. 2009. Manajemen Sumber Daya Manusia Konsep, Teori dan Pengembangan Dalam Konteks Organisasi Publik. Yogyakarta: Graha Ilmu.

Sumarsono. 2010. Ekonomi Sumber Daya Manusia Teori dan Kebijakan Publik. Yogjakarta: Graha Ilmu. 
Surjadi. 2009. Pengembangan

Kinerja Pelayanan Publik.

Bandung: PT. Refika Adi

Tama.

Sutrisno, Edy. 2012. Manajemen

Sumber Daya Manusia. Jakarta:

Kencana.

\section{Undang-Undang}

Undang-Undang Nomor 5 Tahun 2014 tentang ASN 